\title{
Prevalence of Allelic and Genotypic Variants of Il4, Il10, Il12b and Tlr2 Gene Polymorphism in Patients with Chronic Polypoid Rhinosinusitis
}

\section{J.A.Djuraev}

\begin{abstract}
Chronic polyposis rhinosinusitis (CPRS) is an important medical and social problem due to its prevalence, combination with other diseases (bronchial asthma, cystic fibrosis), prolonged recurrent course, which leads to a decrease in the quality of life and performance of patients. Bronchopulmonary, rhinogenic orbital and intracranial complications arising against the background of chronic sinusitis not only worsen the quality of life of patients, but also sometimes lead to long-term disability, and sometimes to disability. The results of our study demonstrated that the distribution of the genotypes of polymorphisms of all genes corresponded to the expected, i.e., in this case, the Hardy-Weinberg equilibrium is fulfilled in both groups. Both samples rs2243250 of the IL4 gene were characterized by high frequencies of the unfavorable $C$ allele and the heterozygous $T$ / C genotype, rs3212227 of the IL12B gene of the A allele and the heterozygous $A$ / $C$ genotype, rs1800895 $592 C>A$ in the IL10 gene of the A, $C$ alleles, and heterozygous $C$ rs5743708 in the TLR2 gene of the $C$ allele and the heterozygous $C$ / T genotype, hence the high level of genetic variability of the studied genes.
\end{abstract}

Keywords: Polyps, Nose, Polymorphism, Gene, Locus, Allele.

\section{INTRODUCTION}

Chronic polyposis rhinosinusitis (CPRS) is classified as an urgent problem of otorhinolaryngology due to the high prevalence of the disease and its medico-social significance $[1,2,3]$.

The last decades have been characterized by an increasing scale of study of the prevalence of CPRS, but the results of the studies differ in a variety of methods, and therefore the data obtained are not very comparable. Summarizing the data of world statistics, we can conclude that CPRS affects $2-4 \%$ of the population, while in $40 \%$ of patients CPRS is combined with bronchial asthma. All researchers agree that in recent years all over the world, there has been a tendency towards an increase in the incidence of CPRS [4,5].

CPRS is an important medical and social problem due to its prevalence, combination with other diseases (bronchial asthma, cystic fibrosis), prolonged recurrent course, which leads to a decrease in the quality of life and performance of patients.

Manuscript received on 21 July 2021 | Revised Manuscript received on 10 August 2021 | Manuscript Accepted on 15 August 2021 | Manuscript published on 30 August 2021.

* Correspondence Author

Djuraev Jamolbek Abdukhakhorovich*, Doctor of Philosophy (PhD), Senior Teacher, Department of Otolaryngology and Stomatology of Tashkent Medical Academy, Republic of Uzbekistan. Email: drdjuraev@.mail.ru

(C) The Authors. Published by Lattice Science Publication (LSP). This is an open access article under the CC-BY-NC-ND license (http://creativecommons.org/licenses/by-nc-nd/4.0/)
Arising against the background of chronic sinusitis, bronchopulmonary, rhinogenic orbital and intracranial complications not only worsen the quality of life of patients, but sometimes lead to long-term disability, and sometimes to disability $[6,7,8,9,10]$.

Epidemiological data presented in the literature differ depending on the characteristics of the studied populations, since the prevalence of CPRS depends on many environmental, biological and social factors. In Europe, the average outpatient visitation rate for CPRS patients is 4.9 per 10,000 population. In hospitals, such patients account for an average of $7.5 \%$ of the number of patients being treated $[11,12]$. According to other data, in the outpatient network, patients with CPRS make up no more than 5\% of those who turn to an otorhinolaryngologist and about $4 \%$ of those who turn to an allergist, moreover, the appeal often takes place due to a relapse of the disease than due to a newonset disease [13]. The proportion of men and women suffering from CPRS is approximately the same. According to some authors, in the North-West region of Russia in the structure of circulation, the ratio of men and women corresponds to $1.7: 1.80 \%$ of newly diagnosed patients are in people over 40 years of age. In the age group under 20 , this pathology is practically not noted [14]. The prevalence among patients with CPRS of persons aged 50 and over is noted in other works devoted to the epidemiology of CPRS $[15,16,17]$. Some scientists, having analyzed the data of the world literature concerning the epidemiology of CPRS, concluded that the average prevalence of CPRS in Russia is 3 times lower than the average European level. In most cases, CPRS occurs in men. The average age of a patient with CPRS in Europe is about 50 years, which is 8\% lower than in northern European countries. However, the above results are based on a statistical analysis of medical examination data. Foreign authors believe that the information obtained in this way is actually lower than it actually is. He confirms his conclusions by the fact that as a result of sectional studies, nasal polyps are found in 32\% of cases, which significantly exceeds the results of clinical and epidemiological studies $[18,19]$.

Epidemiological studies of CPRS, to exclude the influence of external factors, carried out with an interval of 5 years, indicate that in selected time intervals in each specific region, the prevalence of the disease does not change significantly. For a number of reasons (environmental conditions, social and drug load, changes in the functional indicators of the most important homeostatic systems of the human body, etc.), one cannot expect a decrease in the incidence of CPRS.

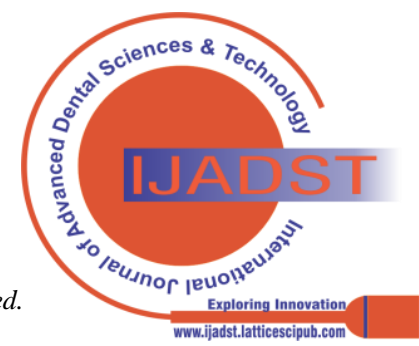


The stability of CPRS incidence rates, regardless of regional characteristics or other external factors, is considered by leading otolaryngologists to be the basis for a more detailed study of the causes of this nosology [20,21].

The fairly widespread prevalence of CPRS along with the lack of remedies for curing the disease, a variety of hypotheses of etiology dictate the need for further study of all links in the pathogenesis and clinical features of the course of the disease. In the coming century of "biological medicine", the availability of high technologies of medical genetics makes it possible to reveal the individual characteristics of the most important regulatory systems of the body, which opens up new prospects for studying the etiology and pathogenesis of CPRS.

\section{MATERIAL AND METHODS}

In accordance with the purpose of the study and to fulfill the assigned tasks, clinical studies were carried out in 140 patients with CPRS and with chronic rhinosinusitis, who were examined and treated at the ENT department of the multidisciplinary clinic of the Tashkent Medical Academy in 2017-2020. The control group consisted of 50 healthy volunteers aged 19 to 70 years from among the employees of the multidisciplinary clinic of the Tashkent Medical Academy. All volunteers included in the study, during the last month before the start of the study, did not tolerate acute diseases, primarily of an infectious nature, and did not have a chronic pathology of inflammatory genesis. Molecular genetic research methods. For real-time PCR, a commercial kit with SYBRGreen I (Litekh, Russia) was used. The polymorphism of five positions of cytokine genes was studied: IL4, IL10, IL12B, TLR2. Genotyping of the samples was carried out using allele-specific polymerase chain reaction (PCR) in real time on a DT-96 device (DNATechnology) using the SYBR Green I intercalating dye. The reaction mixture corresponded to the manufacturer's recommendations.

The reaction began with the activation phase of Taq polymerase (93 ${ }^{\circ} \mathrm{C}, 1 \mathrm{~min}$.). The next 35 PCR cycles consisted of denaturation $\left(93^{\circ} \mathrm{C}, 10\right.$ sec.), Annealing (64 ${ }^{\circ}$ C, 15 sec.) And elongation ( $72^{\circ} \mathrm{C}, 20$ sec.) Phases. The signal was read at the stage of elongation.

\section{RESULTS AND DISCUSSION}

Tables 1 and 2 show the results of calculating the deviation of the expected and observed frequencies of distribution of alleles and genotypes of the C589T rs2243250 polymorphism of the IL4 gene for RHW in patients with CPRS and CRS. In both groups, the actual distribution of the rs2243250 polymorphism genotypes corresponded to those expected at Hardy-Weinberg equilibrium (RHW). The frequency of $\mathrm{C}$ and $\mathrm{T}$ alleles, respectively, was 0.82 and 0.18 in the main group and 0.91 and 0.09 in the control group.

In the main pooled group of patients, the observed and expected frequencies of $\mathrm{C} / \mathrm{C}, \mathrm{C} / \mathrm{T}$ and $\mathrm{T} / \mathrm{T}$ genotypes were 0.69 / 0.68, 0.27 / 0.29 and 0.04 / 0.03, respectively. In the comparative group, the frequency of these genotypes was 0.84 / $0.83,0.15$ / 0.16 and $0.01 / 0.01$. As can be seen, in both groups studied, the difference between the expected and observed frequencies of genotypes was statistically insignificant $(\chi 2<1.59$; $\mathrm{P}>0.05)$.

Table 1. Expected and observed frequencies of distribution of genotypes of rs2243250 polymorphism of the IL4 gene by RHW in the main group of patients with CPRS and CRS

\begin{tabular}{|c|c|c|c|c|c|}
\hline \multicolumn{6}{|c|}{ Main group (patients with CPRS and CRS) } \\
\hline Alleles & Allele frequency & & & & \\
\hline C & 0,82 & & & & \\
\hline $\mathbf{T}$ & 0,18 & & & & \\
\hline \multirow{2}{*}{ Genotypes } & \multicolumn{2}{|c|}{ Genotype frequency } & $\mathrm{Yi}$ & & $d f$ \\
\hline & Observed & Expected & $\lambda 12$ & $P$ & uा \\
\hline $\mathbf{C} / \mathbf{C}$ & 0,69 & 0,68 & 0,01 & & \\
\hline $\mathrm{C} / \mathrm{T}$ & 0,27 & 0,29 & 0,12 & & \\
\hline $\mathbf{T} / \mathbf{T}$ & 0,04 & 0,03 & 0,29 & & \\
\hline Total & 1 & 1 & 0,43 & 0,489 & 1 \\
\hline
\end{tabular}

Table 2. Expected and observed frequencies of distribution of genotypes of rs2243250 polymorphism of the IL4 gene by RHW in the group of conditionally healthy donors.

\begin{tabular}{|c|c|c|c|c|c|}
\hline \multicolumn{6}{|c|}{ Control group } \\
\hline Alleles & Allele frequency & & & & \\
\hline $\mathbf{C}$ & 0,91 & & & & \\
\hline $\mathbf{T}$ & 0,09 & & & & \\
\hline \multirow{2}{*}{ Genotypes } & \multicolumn{2}{|c|}{ Genotype frequency } & \multirow{2}{*}{$\mathrm{Xi2}$} & \multirow[b]{2}{*}{$\mathrm{p}$} & \multirow[b]{2}{*}{ df } \\
\hline & Observed & Expected & & & \\
\hline $\mathbf{C} / \mathbf{C}$ & 0,84 & 0,83 & 0 & & \\
\hline $\mathrm{C} / \mathrm{T}$ & 0,15 & 0,16 & 0,06 & & \\
\hline $\mathbf{T} / \mathbf{T}$ & 0,01 & 0,01 & 0,31 & & \\
\hline Total & 1 & 1 & 0,37 & 0,52 & 1 \\
\hline
\end{tabular}

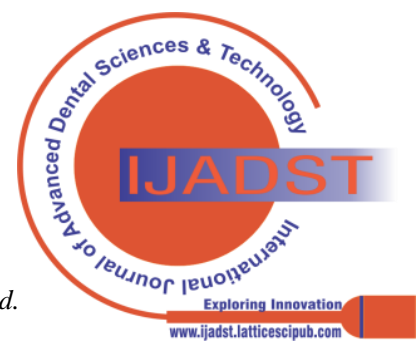


In the main and control groups, the observed numbers of heterozygotes (Hobs) of this polymorphism were lower than expected due to the lack of the observed number of heterozygotes, and the relative deviation of the observed heterozygosity from the expected was: $\mathrm{D}=-0.1$ and $\mathrm{D}=-$ 0.04 , respectively (Table 3 ).
These data indicate lower frequencies of the identified actual heterozygotes, compared with the theoretically calculated heterozygotes, this is also evidenced by the negative value of the fixation index ( $D=-0.08$ and $D=-$ 0.07 ) and a rather high level of heterozygosity of this locus in the studied groups. ( $\operatorname{Hexp}>0,1)$.

Table 3. Difference between expected and observed frequencies of heterozygosity

\begin{tabular}{|c|c|c|c|}
\hline Groups & $\mathbf{H}_{\mathbf{0}}$ & $\mathbf{H}_{\mathbf{e}}$ & $\mathbf{D}^{*}$ \\
\hline Main group & 0,27 & 0,29 & $-0,08$ \\
\hline Control group & 0,15 & 0,16 & $-0,07$ \\
\hline
\end{tabular}

Note: $\mathrm{D}^{*}=\left(\mathrm{H}_{\mathrm{o}}-\mathrm{H}_{\mathrm{e}}\right) / \mathrm{H}_{\mathrm{e}}$

In patients with CPRS, the expected distribution of the rs2243250 genotypes of the IL4 gene also corresponded to that expected in RHW (Table 4). In the subgroup of patients, a slight deviation of the observed distribution of the heterozygous genotype from the expected one $(0.19$ versus
0.17 , respectively) was revealed, and the deviation was due to the lack of heterozygotes due to an increase in the frequency of homozygotes. However, such a difference turned out to be statistically insignificant, and the distribution of this genotype also corresponded to that expected in RHW.

Table 4. Expected and observed frequencies of distribution of genotypes of rs2243250 polymorphism of the IL4 gene by RHW in subgroups of patients with CPRS

\begin{tabular}{|c|c|c|c|c|c|}
\hline \multicolumn{6}{|c|}{ CPRS } \\
\hline Alleles & Allele frequency & & & & \\
\hline C & 0,9 & & & & \\
\hline $\mathbf{T}$ & 0,1 & & & & \\
\hline \multirow{2}{*}{ Genotypes } & \multicolumn{2}{|c|}{ Genotype frequency } & \multirow{2}{*}{$\mathrm{Xi} 2$} & \multirow{2}{*}{$\mathrm{p}$} & \multirow[b]{2}{*}{$\mathrm{df}$} \\
\hline & Observed & Expected & & & \\
\hline $\mathrm{C} / \mathrm{C}$ & 0,81 & 0,82 & 0 & & \\
\hline $\mathrm{C} / \mathrm{T}$ & 0,19 & 0,17 & 0,06 & & \\
\hline $\mathbf{T} / \mathbf{T}$ & 0 & 0,01 & 0,29 & & \\
\hline Total & 1 & 1 & 0,36 & 0,527 & 1 \\
\hline
\end{tabular}

In patients with CRS, the expected distribution of the C589T rs2243250 genotypes of the IL4 gene also corresponded to that expected in RHW (Table 5). In this subgroup of patients, a slight deviation of the observed distribution of the heterozygous genotype from the expected one was revealed ( 0.33 versus 0.36 , respectively), and the deviation was due to a lack of heterozygotes due to an increase in the frequency of homozygotes. However, such a difference turned out to be statistically insignificant, and the distribution of this genotype also corresponded to that expected in RHW.

Table 5. Expected and observed frequencies of distribution of genotypes of rs2243250 polymorphism of the IL4 gene by RHW in subgroups of patients with CRS

\begin{tabular}{|c|c|c|c|c|c|}
\hline \multicolumn{6}{|c|}{ CRS } \\
\hline Alleles & Allele frequency & & & & \\
\hline $\mathbf{C}$ & 0,76 & & & & \\
\hline $\mathbf{T}$ & 0,24 & & & & \\
\hline \multirow{2}{*}{ Genotypes } & \multicolumn{2}{|c|}{ Genotype frequency } & \multirow{2}{*}{ Xi2 } & \multirow{2}{*}{$\mathrm{p}$} & \multirow[b]{2}{*}{ df } \\
\hline & Observed & Expected & & & \\
\hline $\mathrm{C} / \mathrm{C}$ & 0,6 & 0,58 & 0,02 & & \\
\hline $\mathrm{C} / \mathrm{T}$ & 0,33 & 0,36 & 0,15 & & \\
\hline $\mathbf{T} / \mathbf{T}$ & 0,08 & 0,06 & 0,25 & & \\
\hline Total & 1 & 1 & 0,42 & 0,493 & 1 \\
\hline
\end{tabular}

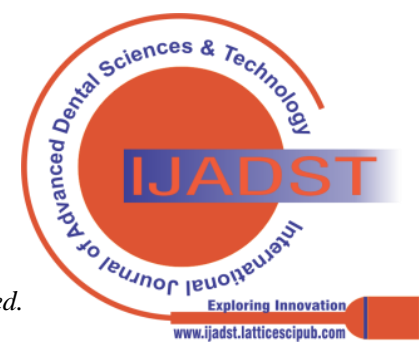


The distribution of alleles and genotypes rs3212227 of the IL12B gene in the studied groups of patients with CPRS, CRS and controls was checked for compliance with the Hardy-Weinberg equilibrium.

Tables 6 and 7 show the results of calculating the deviation of the expected and observed frequencies of distribution of alleles and genotypes of the rs3212227 polymorphism of the IL12B gene by RHW in the general and comparative groups. In both groups, the actual distribution of the rs3212227 polymorphism genotypes corresponded to those expected at Hardy-Weinberg equilibrium (RHW). The frequency of the A and C alleles, respectively, were: 0.89 and 0.11 - in the main group of patients with CPRS, CRS and 0.63 and 0.37 - in the control group.

In the combined group of CPRS and CRS patients, the observed and expected frequencies of the A / A, A / C, and $\mathrm{C} / \mathrm{C}$ genotypes were 0.79 / 0.8, 0.21 / 0.19, and 0.0 / 0.01 , respectively. In the comparative group, the frequency of these genotypes was $0.78 / 0.79,0.22$ / 0.2 , and $0 / 0.01$. As can be seen, in both groups studied, the difference between the expected and observed frequencies of genotypes was statistically insignificant $(\chi 2<1.41 ; \mathrm{P}>0.05)$.

Table 6. Expected and observed frequencies of distribution of genotypes of rs3212227 polymorphism of the IL12B gene for RHW in the main group of patients with CPRS and CRS

\begin{tabular}{|c|c|c|c|c|c|}
\hline \multicolumn{7}{|c|}{ Main } & & & \\
\hline Alleles & Allele frequency & & & \\
\hline A & 0,89 & & & & \\
\hline C & 0,11 & & \multirow{2}{*}{ Xi2 } & $\mathrm{p}$ & $\mathrm{df}$ \\
\hline \multirow{2}{*}{ Genotypes } & Genotype frequency & Expected & & & \\
\hline & Observed & 0,8 & 0,01 & & \\
\hline A/A & 0,79 & 0,19 & 0,19 & & \\
\hline A/C & 0,21 & 0,01 & 0,79 & & \\
\hline C/C & 0 & 1 & 0,99 & 0,307 & 1 \\
\hline Total & 1 & &
\end{tabular}

Table 7. Expected and observed frequencies of distribution of genotypes of the rs3212227 polymorphism of the IL12B gene by RHW in the group of conditionally healthy donors.

\begin{tabular}{|c|c|c|c|c|c|}
\hline \multirow{2}{*}{ Alleles } & Allele frequency & & & & \\
\hline A & $\mathbf{0 , 8 9}$ & & & & \\
\hline C & $\mathbf{0 , 1 1}$ & & & & \\
\hline \multirow{2}{*}{ Genotypes } & Genotype frequency & \multirow{2}{*}{ Xi2 } & $\mathbf{p}$ & df \\
\cline { 2 - 6 } & Observed & Expected & & & \\
\hline A/A & 0,78 & 0,79 & 0,01 & & \\
\hline A/C & 0,22 & 0,2 & 0,22 & & \\
\hline C/C & 0 & 0,01 & 0,88 & & 1 \\
\hline Total & 1 & 1 & 1,11 & 0,28 & \\
\hline
\end{tabular}

In the main and control groups, the observed numbers of heterozygotes (Hobs) of this polymorphism turned out to be lower than expected due to the lack of the observed number of heterozygotes, and the relative deviation of the observed heterozygosity from the expected one was: $\mathrm{D}=-0.1$ and $\mathrm{D}=$ -0.04 , respectively (Table 8 ).
These data indicate lower frequencies of the identified actual heterozygotes, in comparison with the theoretically calculated heterozygotes, this is also evidenced by the negative value of the fixation index $(D=0.12$ and $D=0.12$ ) and a rather high level of heterozygosity of this locus in the studied groups. ( $\left.\mathrm{H}_{\mathrm{exp}}>0,1\right)$.

Table 8. Difference between expected and observed frequencies of heterozygosity.

\begin{tabular}{|c|c|c|c|}
\hline Groups & $\mathbf{H}_{\mathbf{0}}$ & $\mathbf{H}_{\mathbf{e}}$ & $\mathbf{D}^{*}$ \\
\hline $\begin{array}{c}\text { Main } \\
\text { group }\end{array}$ & 0,21 & 0,19 & 0,12 \\
\hline $\begin{array}{c}\text { Control } \\
\text { group }\end{array}$ & 0,22 & 0,2 & 0,12 \\
\hline
\end{tabular}

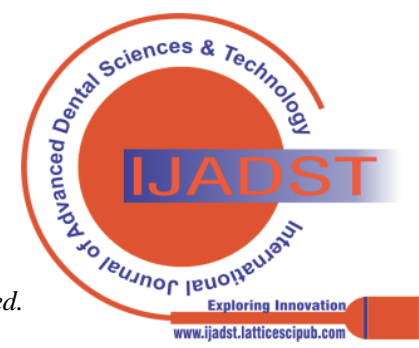


Note: $\mathrm{D}^{*}=\left(\mathrm{H}_{\mathrm{o}}-\mathrm{H}_{\mathrm{e}}\right) / \mathrm{H}_{\mathrm{e}}$

In the subgroups of patients with CPRS, the expected distribution of the rs3212227 genotypes of the IL12B gene also corresponded to that expected in ECV (Table 9). In the subgroup of patients with CPRS, a slight deviation of the observed distribution of the heterozygous genotype from the expected one was revealed ( 0.19 versus 0.17 , respectively).

Table 9. Expected and observed frequencies of distribution of genotypes of rs 1143627 polymorphism of the IL1b gene by RHW in subgroups of patients with CPRS

\begin{tabular}{|c|c|c|c|c|c|}
\hline \multicolumn{6}{|c|}{ CPRS } \\
\hline Alleles & Allele frequency & & & & \\
\hline $\mathbf{A}$ & 0,9 & & & & \\
\hline $\mathrm{C}$ & 0,1 & & & & \\
\hline \multirow{2}{*}{ Genotypes } & \multicolumn{2}{|c|}{ Genotype frequency } & $\mathbf{v}^{*}$ & & \\
\hline & Observed & Expected & X12 & $\mathbf{p}$ & df \\
\hline A /A & 0,81 & 0,82 & 0 & & \\
\hline $\mathrm{A} / \mathrm{C}$ & 0,19 & 0,17 & 0,06 & & \\
\hline $\mathrm{C} / \mathrm{C}$ & 0 & 0,01 & 0,29 & & \\
\hline Total & 1 & 1 & 0,36 & 0,527 & 1 \\
\hline
\end{tabular}

In the subgroups of patients with CRS, the expected distribution of the rs3212227 genotypes of the IL12B gene also corresponded to that expected in RHW (Table 10). In the subgroup of patients, a slight deviation of the observed distribution of the heterozygous genotype from the expected one was revealed ( 0.23 versus 0.2 , respectively), and the deviation was due to a lack of heterozygotes due to an increase in the frequency of homozygotes.

Table 10. Expected and observed frequencies of distribution of genotypes of rs 1143627 polymorphism of the IL1b gene by RHW in the subgroup of patients with CRS

\begin{tabular}{|c|c|c|c|c|c|}
\hline \multicolumn{6}{|c|}{ CRS } \\
\hline Alleles & Allele frequency & & & & \\
\hline A & 0,89 & & & & \\
\hline $\mathrm{C}$ & 0,11 & & & & \\
\hline \multirow{2}{*}{ Genotypes } & \multicolumn{2}{|c|}{ Genotype frequency } & & & \\
\hline & Observed & Expected & $\mathrm{Xi2}$ & $\mathbf{p}$ & df \\
\hline $\mathbf{A} / \mathbf{A}$ & 0,78 & 0,79 & 0,01 & & \\
\hline $\mathbf{A} / \mathbf{C}$ & 0,23 & 0,2 & 0,13 & & \\
\hline $\mathrm{C} / \mathrm{C}$ & 0 & 0,01 & 0,51 & & \\
\hline Total & 1 & 1 & 0,64 & 0,405 & 1 \\
\hline
\end{tabular}

To determine the stability of the Uzbek population for the polymorphic trait rs1800895 592 C> A in the IL10 gene, the distribution of genotypes for the studied polymorphic loci was checked for compliance with RHW using Fisher's exact test in the main and control groups (unrelated chromosomes).

According to these data, the observed frequencies of RHW genotypes were found to correspond to the chosen significance level $\mathrm{P}>0.05$, with $\chi 2=1.22$ and $\mathrm{P}=0.26$.
Namely, the frequency of the A / A genotype in the population group completely coincides with the expected values - $86.6 \%$ and $87 \%$, respectively, and the difference between the observed (13.4\%) and theoretical (12.5\%) frequencies of heterozygotes is $1 \%$, which determines a statistically insignificant excess of heterozygotes in the population. There were also no statistically significant differences in the indices for homozygotes for this polymorphic variant (Tables 11 and 12).

Table 11. Expected and observed frequencies of distribution of genotypes of the locus for RHW in the main group (polymorphism rs1800895 $592 \mathrm{C}>\mathrm{A}$ in the IL10 gene)

\begin{tabular}{|c|c|c|c|c|c|}
\hline \multicolumn{6}{|c|}{ Main group } \\
\hline Alleles & Allele frequency & & & & \\
\hline C & 0,81 & & & & \\
\hline A & 0,19 & & & \multirow{3}{*}{$\mathrm{p}$} & \\
\hline \multirow{2}{*}{ Genotypes } & \multicolumn{2}{|c|}{ Genotype frequency } & \multirow{2}{*}{$\mathrm{Xi} 2$} & & \multirow{2}{*}{$\mathrm{df}$} \\
\hline & Observed & Expected & & & \\
\hline $\mathrm{C} / \mathrm{C}$ & 0,68 & 0,66 & 0,04 & & \\
\hline C / A & 0,27 & 0,31 & 0,38 & & \\
\hline A/ A & 0,06 & 0,04 & 0,8 & & \\
\hline Total & 1 & 1 & 1,22 & 0,261 & 1 \\
\hline
\end{tabular}


Prevalence of Allelic and Genotypic Variants of Il4, Il10, Il12b and Tlr2 Gene Polymorphism in Patients with Chronic Polypoid Rhinosinusitis

Table 12. Expected and observed frequencies of distribution of genotypes of the locus by RHW in the control group (polymorphism rs1800895 $592 \mathrm{C}>\mathrm{A}$ in the IL10 gene)

\begin{tabular}{|c|c|c|c|c|c|}
\hline \multicolumn{6}{|c|}{ Control group } \\
\hline Alleles & Allele frequency & & & & \\
\hline C & 0,83 & & & & \\
\hline A & 0,17 & & \multirow{3}{*}{$\mathrm{Xi2}$} & \multirow{3}{*}{$\mathrm{p}$} & \multirow[b]{3}{*}{$\mathrm{df}$} \\
\hline \multirow{2}{*}{ Genotypes } & \multicolumn{2}{|c|}{ Genotype frequency } & & & \\
\hline & Observed & Expected & & & \\
\hline $\mathrm{C} / \mathrm{C}$ & 0,7 & 0,69 & 0,01 & & \\
\hline $\mathbf{C} / \mathbf{A}$ & 0,26 & 0,28 & 0,14 & & \\
\hline A/ A & 0,04 & 0,03 & 0,35 & & \\
\hline Total & 1 & 1 & 0,5 & 0,457 & 1 \\
\hline
\end{tabular}

In the main and control groups, the observed numbers of heterozygotes (Hobs) of this polymorphism were also, as in all studies, lower than expected due to the lack of the observed number of heterozygotes, and the relative deviation of the observed heterozygosity from the expected was: $\mathrm{D}=-0.1$ and $\mathrm{D}=-0.04$, respectively ( Table 13 ).
These data indicate lower frequencies of the identified actual heterozygotes, in comparison with the theoretically calculated heterozygotes, this is also evidenced by the negative value of the fixation index $(\mathrm{D}=-0.13$ and $\mathrm{D}=-$ 0.08 ) and a rather high level of heterozygosity of this locus in the studied groups. ( $H \exp >0,1)$.

Table 13. Difference between expected and observed frequencies of heterozygosity.

\begin{tabular}{|c|c|c|c|}
\hline Groups & $\mathbf{H}_{\mathbf{0}}$ & $\mathbf{H}_{\mathbf{e}}$ & $\mathbf{D}^{*}$ \\
\hline Main group & 0,27 & 0,31 & $-0,13$ \\
\hline $\begin{array}{c}\text { Control } \\
\text { group }\end{array}$ & 0,26 & 0,28 & $-0,08$ \\
\hline
\end{tabular}

Note: $\mathrm{D}^{*}=\left(\mathrm{H}_{\mathrm{o}}-\mathrm{H}_{\mathrm{e}}\right) / \mathrm{H}_{\mathrm{e}}$

In the subgroups of patients with CPRS, the expected distribution of rs1800895 592 C> A genotypes in the IL10 gene also corresponded to that expected in RHW (Table 14).
In the subgroup of patients with CPRS, a significant deviation of the observed distribution of $\mathrm{C}$ and $\mathrm{A}$ alleles from the expected was revealed (0.82 versus 0.18 , respectively).

Table 14. Expected and observed frequencies of distribution of genotypes of rs1800895 $592 \mathrm{C}>\mathrm{A}$ polymorphism in the IL10 gene by RHW in subgroups of patients with CPRS

\begin{tabular}{|c|c|c|c|c|c|}
\hline \multicolumn{7}{|c|}{ CPRS } & & & \\
\hline Alleles & Allele frequency & & & & \\
\hline C & 0,82 & & & & \\
\hline A & 0,18 & \multirow{2}{*}{ Xi2 } & p & \\
\hline \multirow{2}{*}{ Genotypes } & Genotype frequency & & \\
\hline & Observed & Expected & & & \\
\hline C/C & 0,71 & 0,68 & 0,04 & & \\
\hline C/A & 0,24 & 0,29 & 0,36 & & \\
\hline A/A & 0,06 & 0,03 & 0,84 & & \\
\hline Total & 1 & 1 & 1,23 & 0,258 & 1 \\
\hline
\end{tabular}

In the subgroups of patients with CRS, the expected distribution of the rs1800895 $592 \mathrm{C}>$ A genotypes in the IL10 gene also corresponded to that expected in RHW (Table 15). In the subgroup of patients, a significant deviation of the observed distribution of $\mathrm{C}$ and $\mathrm{A}$ alleles from the expected was revealed (0.81 versus 0.19 , respectively). 
Table 15. Expected and observed frequencies of distribution of rs1800895 $592 \mathrm{C}>\mathrm{A}$ polymorphism genotypes in the IL10 gene by RHW in subgroups of patients with CRS

\begin{tabular}{|c|c|c|c|c|c|}
\hline \multicolumn{6}{|c|}{ CRS } \\
\hline Alleles & Allele frequency & & & & \\
\hline C & 0,81 & & & & \\
\hline A & 0,19 & & & & \\
\hline \multirow{2}{*}{ Genotypes } & \multicolumn{2}{|c|}{ Genotype frequency } & \multirow{2}{*}{$\mathrm{Xi} 2$} & \multirow{2}{*}{$\mathrm{p}$} & \multirow[b]{2}{*}{$\mathrm{df}$} \\
\hline & Observed & Expected & & & \\
\hline $\mathrm{C} / \mathrm{C}$ & 0,68 & 0,66 & 0,01 & & \\
\hline C/A & 0,28 & 0,3 & 0,12 & & \\
\hline $\mathbf{A} / \mathbf{A}$ & 0,05 & 0,04 & 0,25 & & \\
\hline Total & 1 & 1 & 0,38 & 0,515 & 1 \\
\hline
\end{tabular}

Tables 16 and 17 show the results of calculating the deviation of the expected and observed frequencies of distribution of alleles and genotypes of the rs5743708 Arg753Gln polymorphism in the TLR2 gene for RHW in patients with CPRS and CRS. In both groups, the actual distribution of the rs5743708 polymorphism genotypes corresponded to those expected at Hardy-Weinberg equilibrium (RHW). The frequency of Arg and Gln alleles, respectively, was 0.87 and 0.13 in the main group and 0.88 and 0.11 in the control group.
In the main pooled group of patients, the observed and expected frequencies of Arg / Arg, Arg / Gln, and Gln / Gln genotypes were $0.76 / 0.75,0.21 / 0.23$, and $0.03 / 0.02$, respectively. In the comparative group, the frequency of these genotypes was $0.88 / 0.87,0.11 / 0.13$ and $0.01 / 0.0$. As can be seen, in both groups studied, the difference between the expected and observed frequencies of genotypes was statistically insignificant. $(\chi 2<2.01 ; \mathrm{P}>0.05)$.

Table 16. Expected and observed frequencies of distribution of genotypes of rs5743708 Arg753Gln polymorphism in the TLR2 gene by RHW of the main groups of patients with CPRS and CRS

\begin{tabular}{|c|c|c|c|c|c|}
\hline \multicolumn{6}{|c|}{ Main group } \\
\hline Alleles & Allele frequency & & & & \\
\hline Arg & 0,87 & & & & \\
\hline Gln & 0,13 & & & & \\
\hline \multirow{2}{*}{ Genotypes } & \multicolumn{2}{|c|}{ Genotype frequency } & \multirow{2}{*}{$\mathrm{Xi} 2$} & \multirow{2}{*}{$\mathrm{p}$} & \multirow[b]{2}{*}{$\mathrm{df}$} \\
\hline & Observed & Expected & & & \\
\hline Arg/ Arg & 0,76 & 0,75 & 0,01 & & \\
\hline Arg/Gln & 0,21 & 0,23 & 0,13 & & \\
\hline Gln /Gln & 0,03 & 0,02 & 0,42 & & \\
\hline Total & 1 & 1 & 0,56 & 0,437 & 1 \\
\hline
\end{tabular}

Table 17. Expected and observed frequencies of distribution of genotypes of rs5743708 Arg753Gln polymorphism in the TLR2 gene for RHW in the group of conditionally healthy donors.

\begin{tabular}{|c|c|c|c|c|c|}
\hline \multicolumn{9}{|c|}{ Control } & & & \\
\hline Alleles & Allele frequency & & & \\
\hline Arg & 0,93 & & & & \\
\hline Gln & 0,07 & \multirow{2}{*}{ Xi2 } & $\mathrm{p}$ & \multirow{2}{*}{$\mathrm{df}$} \\
\hline \multirow{2}{*}{ Genotypes } & Genotype frequency & Expected & 0,01 & & \\
\hline & Observed & 0,87 & 0,19 & & \\
\hline Arg/Arg & 0,88 & 0,13 & 1,26 & & \\
\hline Arg/GIn & 0,01 & 0 & 1,45 & 0,221 & 1 \\
\hline Gln/Gln & 1 & 1 & & \\
\hline Total & & & & & \\
\hline
\end{tabular}

In the main and control groups, the observed numbers of heterozygotes (Hobs) of this polymorphism turned out to be lower than expected due to the lack of the observed number of heterozygotes, and the relative deviation of the observed heterozygosity from the expected one was: $\mathrm{D}=-0.09$ and $\mathrm{D}$ $=-0.14$, respectively (Table 18 ). actual heterozygotes, compared with the theoretically
These data indicate lower frequencies of the identified

calculated heterozygotes, this is also evidenced by the negative value of the fixation index ( $D=-0.08$ and $D=-$ 0.07 ) and a rather high level of heterozygosity of this locus in the studied groups. ( $\left.\mathrm{H}_{\mathrm{exp}}>0,1\right)$.

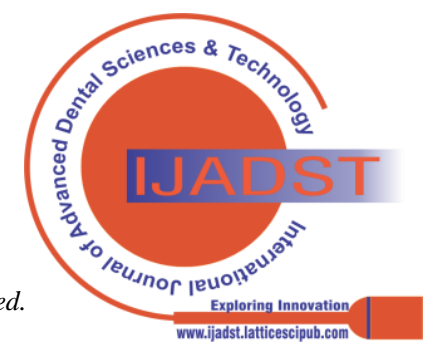


Prevalence of Allelic and Genotypic Variants of Il4, Il10, Il12b and Tlr2 Gene Polymorphism in Patients with Chronic Polypoid Rhinosinusitis

Table 18. Difference between expected and observed frequencies of heterozygosity

\begin{tabular}{|c|c|c|c|}
\hline Groups & $\mathbf{H}_{\mathbf{0}}$ & $\mathbf{H}_{\mathbf{e}}$ & $\mathbf{D}^{*}$ \\
\hline $\begin{array}{c}\text { Main } \\
\text { group }\end{array}$ & 0,21 & 0,23 & $-0,09$ \\
\hline $\begin{array}{c}\text { Control } \\
\text { group }\end{array}$ & 0,11 & 0,13 & $-0,14$ \\
\hline
\end{tabular}

Note: $\mathrm{D}^{*}=\left(\mathrm{H}_{\mathrm{o}}-\mathrm{H}_{\mathrm{e}}\right) / \mathrm{H}_{\mathrm{e}}$
In patients with CPRS, the expected distribution of rs5743708 Arg753Gln genotypes in the TLR2 gene also corresponded to that expected in RHW (Table 19). In the subgroup of patients, a slight deviation of the observed distribution of the heterozygous genotype from the expected one ( 0.19 versus 0.17 , respectively) was revealed, and the deviation was due to the lack of heterozygotes due to an increase in the frequency of homozygotes. However, such a difference turned out to be statistically insignificant, and the distribution of this genotype also corresponded to that expected in RHW.

Table 19. Expected and observed frequencies of distribution of rs5743708 Arg753Gln polymorphism genotypes in the TLR2 gene for RHW in patients with CPRS

\begin{tabular}{|c|c|c|c|c|c|}
\hline \multicolumn{6}{|c|}{ CPRS } \\
\hline Alleles & Allele frequency & & & & \\
\hline Arg & 0,87 & & & & \\
\hline Gln & 0,13 & & & & \\
\hline \multirow{2}{*}{ Genotypes } & \multicolumn{2}{|c|}{ Genotype frequency } & \multirow{2}{*}{ Xi2 } & \multirow{2}{*}{$\mathrm{p}$} & \multirow[b]{2}{*}{ df } \\
\hline & Observed & Expected & & & \\
\hline Arg/ Arg & 0,77 & 0,76 & 0,01 & & \\
\hline Arg/Gln & 0,19 & 0,22 & 0,13 & & \\
\hline Gln /Gln & 0,03 & 0,02 & 0,45 & & \\
\hline Total & 1 & 1 & 0,6 & 0,421 & 1 \\
\hline
\end{tabular}

In patients with CRS, the expected distribution of Arg753Gln genotypes in the TLR2 gene also corresponded to that expected in RHW (Table 20). In this subgroup of patients, a slight deviation of the observed distribution of the heterozygous genotype from the expected one ( 0.6 versus 0.58 , respectively) was revealed, and the deviation was due to the lack of heterozygotes due to an increase in the frequency of homozygotes. However, such a difference turned out to be statistically insignificant, and the distribution of this genotype also corresponded to that expected in RHW.

Table 20. Expected and observed frequencies of distribution of genotypes of rs5743708 Arg753Gln polymorphism in the TLR2 gene by RHW in subgroups of patients with CRS

\begin{tabular}{|c|c|c|c|c|c|}
\hline \multicolumn{6}{|c|}{ CRS } \\
\hline Alleles & Allele frequency & & & & \\
\hline C & 0,76 & & & & \\
\hline $\mathbf{T}$ & 0,24 & & & & \\
\hline \multirow{2}{*}{ Genotypes } & \multicolumn{2}{|c|}{ Genotype frequency } & $\mathrm{Xi}$ & $\mathrm{D}$ & \\
\hline & Observed & Expected & $\Lambda 12$ & $\mathrm{P}$ & df \\
\hline $\mathrm{C} / \mathrm{C}$ & 0,6 & 0,58 & 0,02 & & \\
\hline $\mathrm{C} / \mathrm{T}$ & 0,33 & 0,36 & 0,15 & & \\
\hline $\mathbf{T} / \mathbf{T}$ & 0,08 & 0,06 & 0,25 & & \\
\hline Total & 1 & 1 & 0,42 & 0,493 & 1 \\
\hline
\end{tabular}

\section{CONCLUSION}

Thus, the results of our study demonstrated that the distribution of the genotypes of polymorphisms of all genes corresponded to the expected, i.e., in this case, the HardyWeinberg equilibrium is fulfilled in both groups. Both samples rs2243250 of the IL4 gene were characterized by high frequencies of the unfavorable $\mathrm{C}$ allele and the heterozygous T / C genotype, rs3212227 of the IL12B gene of the A allele and the heterozygous A / C genotype, rs1800895 592 C> A in the IL10 gene of the A, C alleles, and heterozygous $\mathrm{C}$ rs5743708 in the TLR2 gene of the $\mathrm{C}$ allele and the heterozygous $\mathrm{C} / \mathrm{T}$ genotype, hence the high level of genetic variability of the studied genes. The high degree of heterozygosity of the polymorphism of the studied genes makes it the most promising for the subsequent analysis of associations with the development of other multifactorial diseases.

\section{REFERENCES}

1. Alexiou, A., Sourtzi, P., Dimakopoulou, K., et al., Nasal polyps: heredity, allergies, and environmental and occupational exposure, J. Otolaryngol. Head Neck Surg., 2011, no. 40, pp. 58-63.

2. Bosse, Y., Bacot, F., Montpetit, A., et al., Identification of susceptibility genes for complex diseases using pooling-based genome-wide association scans, Hum. Genet., 2009, vol. 125, no. 3, pp. 305-318. doi 10.1007/s00439-009-0626-9 [CrossRef]

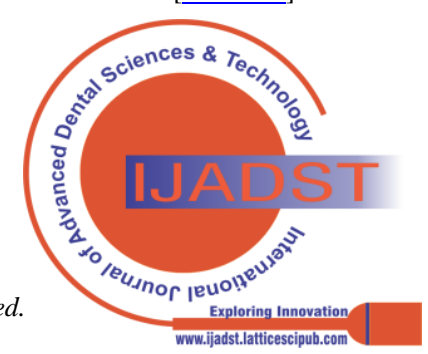


3. Castano, R., Bossé, Y., Endam, L.M., et al., Evidence of association of interleukin-1 receptor-like 1 gene polymorphisms with chronic rhinosinusitis, Am. J. Rhinol. Allergy., 2009, vol. 23, no. 4, pp. $377-$ 384. doi 10.2500/ajra.2009.23.3303 [CrossRef]

4. Chin-An Yang, Bor-Luen Chiang. Toll-like receptor 1 N248S polymorphism affects $\mathrm{T}$ helper 1 cytokine production and is associated with serum immunoglobulin E levels in Taiwanese allergic patients. Journal of Microbiology, Immunology and Infection,Volume 50, Issue 1,2017,Pages 112-117[CrossRef]

5. Elaine Fuertes, Cilla Söderhäll, Nathalie Acevedo, Allan Becker, Michael Brauer, Moira Chan-Yeung, F. Nicole Dijk, Joachim Heinrich, Johan de Jongste, Gerard H. Koppelman, Dirkje S. Postma, Juha Kere, Anita L. Kozyrskyj, Göran Pershagen, Andrew Sandford, Marie Standl, Carla M.T. Tiesler, Melanie Waldenberger, Marit Westman, Christopher Carlsten, Erik Melén. Associations between the $17 q 21$ region and allergic rhinitis in 5 birth cohorts,Journal of Allergy and Clinical Immunology,Volume 135, Issue 2,2015,Pages 573-576[CrossRef]

6. Endam, L.M., Cormier, C., Bossé, Y., et al., Association of IL1A IL1B and TNF gene polymorphisms with chronic rhinosinusitis with and without nasal polyposis: a replication study, Arch. Otolaryngol. Head Neck Surg., 2010, vol. 136, no. 2, pp. 187-192. doi 10.1001/archoto.2009.219 [CrossRef]

7. Harapan Harapan, Jonny K. Fajar, Nur Wahyuniati, Jay R. Anand, Lavanya Nambaru, Kurnia F. Jamil. Non-HLA gene polymorphisms and their implications on dengue virus infection,Egyptian Journal of Medical Human Genetics,Volume 14, Issue 1,2013,Pages 111[CrossRef]

8. Henmyr, V., Vandeplas, G., Halldén, C. et al., Replication study of genetic variants associated with chronic rhinosinusitis and nasal polyposis, J. Allergy Clin. Immunol., 2014, vol. 133, no. 1, pp. 273275. [CrossRef]

9. Hironobu Sunadome, Hisako Matsumoto, Yumi Izuhara, Tadao Nagasaki, Yoshihiro Kanemitsu, Yumi Ishiyama, Chie Morimoto, Tsuyoshi Oguma, Isao Ito, Kimihiko Murase, Shigeo Muro, Takahisa Kawaguchi, Yasuharu Tabara, Kazuo Chin, Fumihiko Matsuda, Toyohiro Hirai. Correlation between eosinophil count, its genetic background and body mass index: The Nagahama Study,Allergology International,2019[CrossRef]

10. Hsu, J., Pedro, C.A., Robert, C.K., et al., Genetics of chronic rhinosinusitis: state of the field and directions forward, J. Allergy Clin. Immunol., 2013, vol. 131, no. 4, pp. 977-993. doi 10.1016/j.jaci.2013.01.028CrossRefPubMedPubMedCentralGoogle Scholar[CrossRef]

11. Oakley, G., Curtin, K., and Orb, Q., Familial risk of chronic rhinosinusitis with and without nasal polyposis: genetics or environment, Int. Forum Allergy Rhinol., 2015, vol. 5, no. 2, pp. 276-282. doi 10.1002/alr.21469 [CrossRef]

12. Ober, C. and Yao, T.C., The genetics of asthma and allergic disease: a 21st century perspective, Immunol. Rev., 2011, vol. 242, pp. 10 30. [CrossRef]

13. Palikhe, N.S., Kim, S.H., Cho, B.Y., et al., IL-13 gene polymorphisms are associated with rhinosinusitis and eosinophilic inflammation in aspirin intolerant asthma, Allergy Asthma Immunol. Res., 2010, vol. 2, no. 2, pp. 134-140. [CrossRef]

14. Pescador, D.B., Isidoro-García, M., and García-Solaesa, V., Genetic association study in nasal polyposis, J. Invest. Allergol. Clin. Immunol., 2012, vol. 22, no. 5, pp. 331-340.

15. Seung-Hyun Kim, Hae-Sim Park, John W. Holloway, Hyoung-Doo Shin, Choon-Sik Park. Association between a TGF $\beta 1$ promoter polymorphism and rhinosinusitis in aspirin-intolerant asthmatic patients, Respiratory Medicine,Volume 101, Issue 3,2007,Pages 490 495[CrossRef]

16. Slavin, Raymond G., et al. "The diagnosis and management of sinusitis: a practice parameter update." Journal of Allergy and Clinical Immunology 116.6 (2005): S13-S47. [CrossRef]

17. Stephanie von Hinke, George Davey Smith, Debbie A. Lawlor, Carol Propper, Frank Windmeijer. Genetic markers as instrumental variables,Journal of Health Economics,Volume 45,2016,Pages 131 148[CrossRef]

18. Thomas Horn, Kumar Reddy Kakularam, Monika Anton, Constanze Richter, Pallu Reddanna, Hartmut Kuhn. Functional characterization of genetic enzyme variations in human lipoxygenases,Redox Biology,Volume 1, Issue 1,2013,Pages 566-577[CrossRef]

19. Tournas, A., Mfuna, L., Bossé, Y., and Filali-Mouhim, A., A pooling-based genome-wide association study implicates the p73 gene in chronic rhinosinusitis, J. Otolaryngol. Head Neck Surg., 2010, vol. 39, no. 2, pp. 188-195.

20. Vereshchagin, M.Yu. and Minkin, A.U., Polypoid rhinosinusitis, Ekol. Chel., 2012, no. 8, pp. 54-58. [CrossRef]
21. Zhang, Y., Desrosiers, M., Mfuna-Endam, L., et al., Demonstration of a common genetic basis to CRS in Chinese and Caucasian populations, J. Allergy Clin. Immunol., 2011, vol. 127, no. 2, p. AB121. doi S0091-6749(10)02424-3 [CrossRef]

\section{AUTHORS PROFILE}

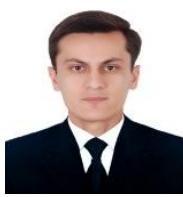

Djuraev Jamolbek Abdukhakhorovich, doctor of philosophy (PhD), senior teacher of the department of Otolaryngology and stomatology of Tashkent Medical Academy, Republic of Uzbekistan, phone: +998974000351, mail: drdjuraev@.mail.ru

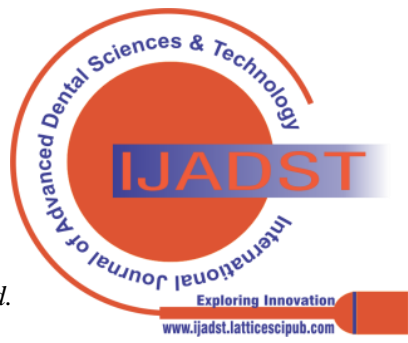

